\title{
JAPAN PRIZE（日本国際賞）
}

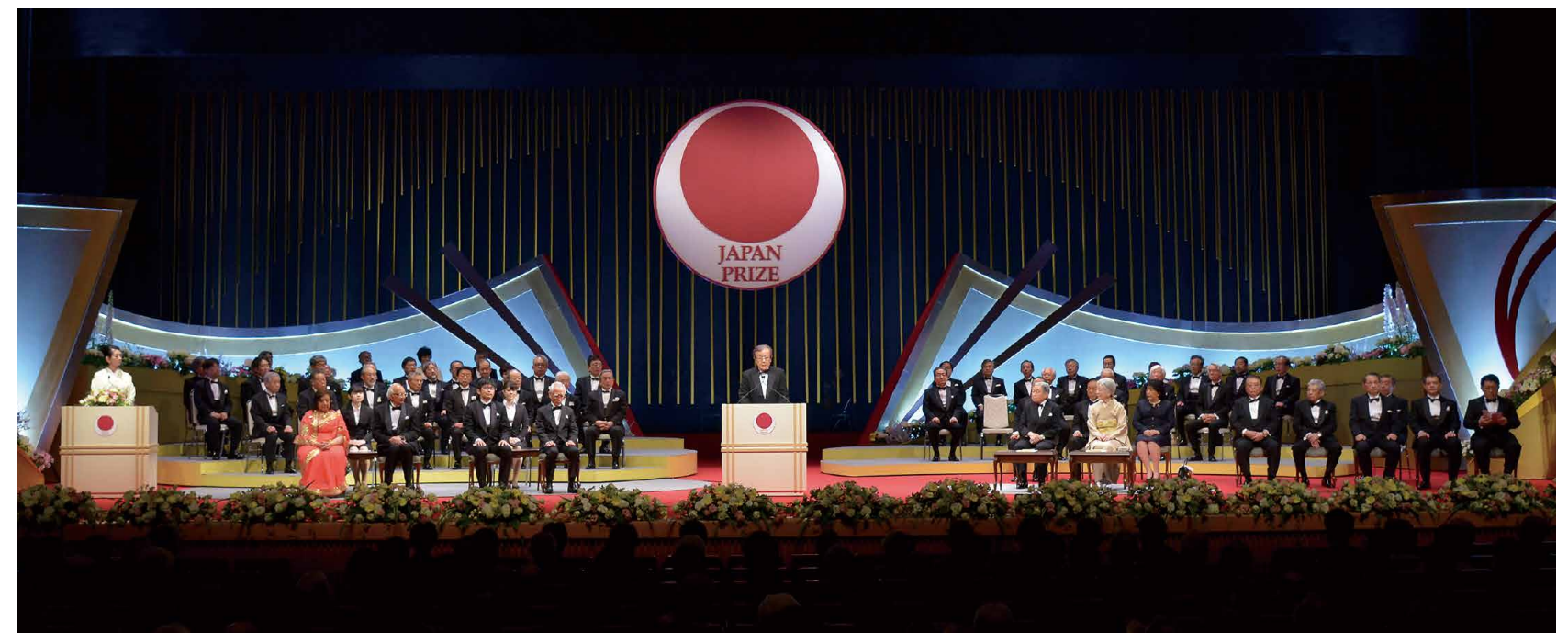

Japan Prize（日本国際賞）は1981年、「世界の科学技術の発展に資するため、国際的に権威のある賞を設 けたい」との政府の構想に民間からの寄付を基に設立され、1983年に閣議了解を得て実現しました。この 賞は、全世界の科学技術者を対象とし、独創的、飛躍的な成果を挙げ、その進歩に大きく寄与し、もって 人類の平和と繁栄に著しく貢献したと認められる人に贈られます。

授賞対象分野は科学技術の全分野を対象とし、科学技術の動向等を勘案して毎年 2 つ分野を指定しま す。原則として各分野 1 件に対して授与され、受賞者には賞状、賞牌及び賞金が贈られます。

授賞式には天皇皇后両陛下が毎回ご臨席、三権の長始め関係大臣と各界の代表のご出席を得、挙行され ます。

閣議了解

\section{日本国際賞の創設について}

財団法人国際科学技術財団が授与す る日本国際賞が、人類の平和と繁栄の ために科学技術が果たす役割について の認識を深め、広く人類の発展に寄与
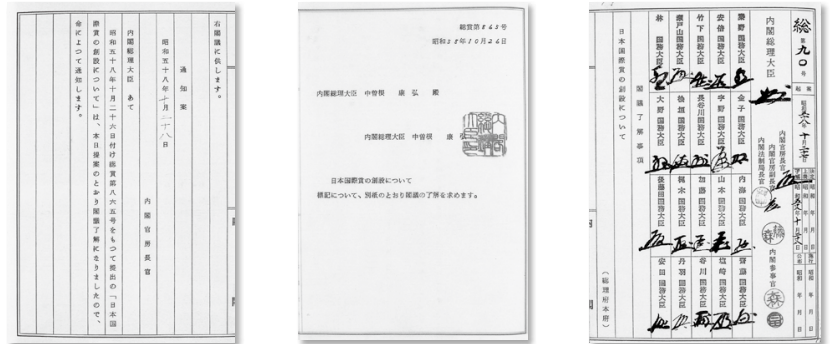

しょうとするものであることにかんがみ、 その実施に関し、関係行政機関は必要な 協力を行うものとする。

（1983年10月28日）
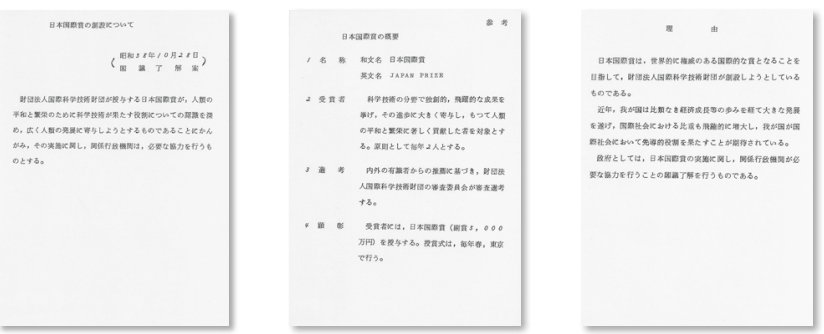


\section{授賞対象分野と審査}

2021年 授賞対象分野

「物理、化学、情報、工学」領域

授賞対象分野：「資源、エネルギー、環境、社会基盤」

背景、選択理由

現代の文明化した暮らしは、要素技術をシステム化して生まれた多様な基盤技術によって支えられています。国連 の持続可能な開発目標 (SDGs) が「最大の地球規模の課題」と位置付ける「あらゆる形態と様相の䝯しさの撲滅」 のためには、社会を支える基盤技術の普及と高度化が欠かせません。

一方、気候変動による影響が顕在化し、緩和策のみならず適応策が必要だとの認識も高まっています。今後、さ らなる災害の増大が懸念される中、レジリアントな社会づくりも契緊の課題です。

都市鉱山も含めた資源の開発・リサイクル技術、水の利用・処理システム、エネルギーマネジメント、防災や減災 の技術、環境変動の予測や対応、さらには都市や交通などに関わる社会基盤技術にイノベーションが強く求められ ています。

\section{対象とする業績}

2021年の日本国際賞は、「資源、エネルギー、環境、社会基盤」の分野において、飛躍的な科学技術の創造·革新· 普及をもたらし、それらを通して人類社会の持続的な発展に寄与するなど、社会に大きく貢献する業績を対象としま す。

\section{「生命、農学、医学」領域}

\section{授賞対象分野：[医学、薬学]}

\section{背景、選択理由}

医学·薬学分野の近年の進歩は目覚ましく、ゲノム医療や再生医療、医療に扔けるロボット活用が急進展する一方、 がん免疫治療薬、抗ウイルス薬といった画期的な医薬品が次々に生み出されています。

それでもなお、高齢化や生活習慣の変化にともなう疾患や新興感染症への対策、病原体やがんの薬剂耐性の出 現などが世界的に大きな問題となっています。

現代の医学・薬学は、工学や情報学との融合を含む新しい医療の創造と普及、新規医薬品の開発・生产、ドラッ グデリバリーシステムの開発などを通じて、人々の健康な生活に一層の貢献をすることが期待されます。

\section{対象とする業績}

2021年の日本国際賞は、「医学、薬学」の分野において、飛躍的な科学技術の発展をもたらし、疾病の「予防」「診 断」「治療」「予後の予測」に関する新たな発見や革新的な技術の開発を通じて、人々の健康増進に寄与すること により、社会に大きく貢献する業績を対象とします。

\section{Japan Prize の推薦と審査}

・国際科学技術財団内に設けられた「分野検討委員会」が、翌々年の日本国際賞の授賞対象となる2分野を決定し、毎年11月に発 表します。同時に財団に登録された世界約 14,000 人以上の推薦人にWEB推㾺システムを通じて受賞候補者の推薦を求めていま す。推薦受付は翌年1月末に締め切られます。

・各分野毎に科学技術面での卓越性を専門的に審查する「審查部会」で厳選された候補者は「審査委員会」に答申され、そこで 社会への貢献度なども含めた総合的な審査が行われ、受賞候補者が推挙されます。

・「審査委員会」からの推挙を受け、毎年11月の財団理事会で受賞者の最終決定が行われます。

・翌年1月には当該年度の受賞者発表を行い、毎年4月に授賞式を開催します。このようにJapan Prizeは、授賞対象分野検討開始か ら授賞式での贈賞まで、約2年をかけた慎重、丁寧なプロセスで運営されています。

2021年受賞者の決定プロセス

2019年

7月 10 月

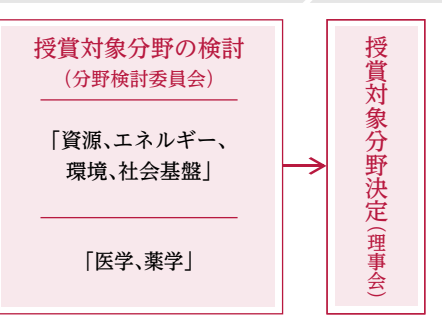
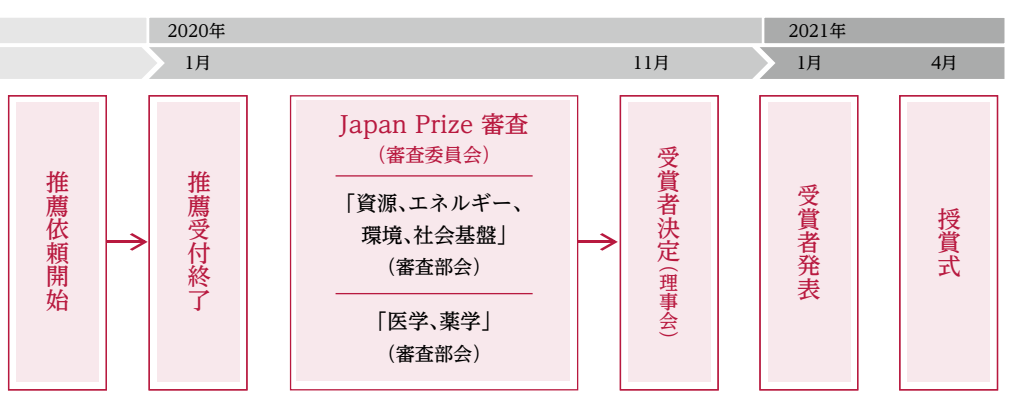